\title{
Understanding Singapore's dynamic parrot trade ecosystem
}

\author{
Anuj Jain, Scott Li Meng Aloysius, Heather Lim, Tim Plonden \\ Ding Li Yong, Jessica Grace Lee and Jacob Phelps
}

\begin{abstract}
Singapore is prominent in the global trade of pet birds, primarily parrots. This includes its role as a key international transit hub, and also its growing domestic market, including for threatened species. There is a need to understand the trade beyond volumes and flows, including consumer knowledge, preferences and behaviours, and interactions with vendors, hobbyist groups and supporting industries. We used three methods to examine this: (1) a questionnaire with stakeholders (including parrot owners, hobbyist group members, breeders and supporting industry professionals), about the motivations for parrot ownership and interest in sustainable trade, (2) semi-structured interviews with key informants about trade dynamics, and (3) a review of online hobbyist groups. Based on our findings, we provide an initial mapping of the country's parrot trade ecosystem. Fifty-one per cent of respondents claimed to be a member of a parrot hobbyist group and $64 \%$ agreed their participation in such groups had encouraged them to purchase more parrots. The majority $(71 \%)$ of parrot owners reported a preference for captive-bred rather than wildcaught parrots, and $72 \%$ were concerned about the illegal hunting of parrots for commercial trade. Most were willing to pay more $(70 \%)$ and wait longer $(73 \%)$ to procure a sustainably sourced parrot. Our approach presents the wildlife trade as a complex social phenomenon, with multiple physical and online channels, regulatory challenges, social networks, and evolving consumer preferences. We also document the pivotal role of hobbyist groups and their untapped potential to leverage these networks to improve sustainable trade.
\end{abstract}

ANUJ JAIN ${ }^{*} \dagger$ (Corresponding author, (1) orcid.org/0000-0001-9837-4163), SCOTT

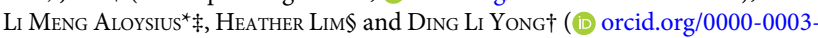
3115-6916) BirdLife International (Asia), 354 Tanglin Road, Singapore 247672, Singapore. E-mail anuj.jain@birdlife.org

Tim PLowden Nature Society (Singapore), Singapore

Jessica Grace Lee Mandai Nature, Singapore

Јасов Phelps (ㅁ) orcid.org/0000-0001-6489-1103) Lancaster Environment Centre, Lancaster University, Lancaster, UK

${ }^{*}$ Contributed equally to this work.

$\dagger$ Also at: Nature Society (Singapore), Singapore

¥Also at: Department of Biological Sciences, National University of Singapore, Singapore

$\$$ Also at: Department of Politics, Philosophy and Economics, Yale-National University of Singapore College, Singapore

Received 20 May 2020. Revision requested 17 June 2020.

Accepted 15 October 2020. First published online 16 August 2021.
Keywords Behaviour change, bird trade, demand reduction, parrot, pet, Singapore, sustainable trade, wildlife trade Supplementary material for this article is available at doi.org/10.1017/So030605320001246

\section{Introduction}

Darrots (Psittaciformes), including macaws, cockatoos, 1 parakeets and lorikeets, are one of the most commonly traded groups in the global pet bird trade (Bush et al., 2014). Although much of this trade is legal and based on captive-bred and/or legally harvested wild animals, a considerable part of the trade is also illegal and unsustainable (Pires, 2012; Olah et al., 2016). Illegal trade has caused declines of many parrot species and populations globally; $28 \%$ of parrot species are categorized as globally threatened, with hunting and trapping the most important threat after habitat loss (Olah et al., 2016). One well-known example of a species severely affected by trapping is Spix's macaw Cyanopsitta spixii, which became extinct in the wild largely as a result of poaching for the pet trade (Butchart et al., 2018).

Singapore is a global trade hub for birds originating from South-east Asia, Africa and Europe, for both domestic trade and commercial re-export to East Asia and the Middle East (TRAFFIC, 2016; UNODC, 2016; Aloysius et al., 2019). This includes a large component of legal trade. Singapore was ranked 6th in the volume of legal CITES-listed parrot imports during 2007-2013 (UNODC, 2016), and nine of the top 10 CITES-listed traded bird species in Singapore during 2005-2016 were parrots (Aloysius et al., 2019). However, the country has also been recurrently implicated in the illegal wildlife trade (Nijman, 2010; Minin et al., 2019), including of threatened parrot species such as the yellowcrested cockatoo Cacatua sulphurea and African grey parrot Psittacus erithacus (Shepherd et al., 2012; Poole \& Shepherd, 2016; UNODC, 2016; Aloysius et al., 2019), despite the Singapore CITES Authority, now part of the Singapore National Parks Board, having tightened enforcement of laws against the illegal wildlife trade since 2019 (Channel News Asia, 2019; Tan, 2019).

Singapore is also a globally significant consumer market for parrots, with an estimated 5,000-10,000 parrot owners (A. Jain, unpubl. data). There are reports of growing domestic demand since 2011 (Chan, 2016; Aloysius et al., 2019), including an estimated $10 \%$ annual increase in parrot sales 
during 2011-2014 (Vasko, 2014). This is consistent with an increase in the number of Singaporean parrot owners in their 30 (Aloysius et al., 2019), contrary to the common perception that bird-keeping is a hobby of older men (Baker, 2014). A number of parrot hobbyist groups have emerged across the country since 2012, with growing membership and public free-fly events (owners demonstrating the ability of their trained pet parrots to return after a period of free flight) that may be drawing wider public attention to parrot ownership (Osada, 2016; Aloysius et al., 2019; Jin, 2019).

Given Singapore's role in both the legal and illegal international trade, and evidence of a large and constantly evolving domestic market for pet animals, there is a need to understand the underlying trade dynamics. Whereas previous studies have focused on market surveys and trade volumes, we consider the network of domestic stakeholders that are shaping trade, including the knowledge, preferences and behaviours of individual pet owners, and their dynamic interactions with traders and hobbyist communities. This frames wildlife trade as a broader social phenomenon, a system of parallel legal and illegal trade channels, shifting trade trends, regulatory challenges, complex social networks and evolving consumer preferences. In particular, we consider the apparent influence of pet hobbyist groups in driving consumer demand. This suggests a need to actively engage these communities to guide the implementation of behaviour change interventions, in addition to individual consumers (Gallagher, 2017; Sivapriyan, 2018; Zheng \& Leung, 2018) who are typically segmented according to their motivations and preferences (Hinsley et al., 2015; Theng et al., 2018; Doughty et al., 2019; Thomas-Walters et al., 2020).

\section{Methods}

\section{Questionnaire}

We conducted a questionnaire survey with 145 parrot owners and other stakeholders (including hobbyist group members, traders, breeders and supporting industry professionals) in Singapore during February-August 2017. This included 40 respondents $(27.6 \%)$ who were approached opportunistically at pet stops, and 105 respondents $(72.4 \%)$ who answered an online version circulated on bird forums and parrot-themed Facebook groups (Supplementary Table 1) or shared via chain referral sampling (Newing, 2011).

The questionnaire comprised 21 questions (Supplementary Material 1) structured into six themes: (1) reasons for keeping parrots, (2) involvement in hobbyist groups, (3) parrot breeding, (4) knowledge and views on conservation, (5) details of parrot ownership (numbers and species), and (6) respondent demographics. We categorized parrots kept by respondents into small $(<200 \mathrm{~g})$, medium $(200-$ $400 \mathrm{~g})$ and large $(>400 \mathrm{~g})$ size classes. The last section of the questionnaire, on conservation, asked respondents to identify native parrot species, and to provide the IUCN Red List conservation status of the parrot species they owned. Respondents were marked correct for these questions if they could identify at least one native parrot and/ or provide the correct Red List status for all the parrots they kept. Overall, each respondent was given a score of o, 1 or 2 depending on the number of correct answers.

Questionnaire results were analysed using descriptive statistics. Generalized linear models (GLM) with a Poisson distribution were used, in $R$ 3.6.o (R Core Team, 2019), to test the association between respondent demographics and views about parrot conservation (Supplementary Table 2). The Shapiro-Wilk test was used to check for normality of variables. Spearman's test was used to examine for potential correlation between variables, as they were non-parametric. No correlations were observed among the dependent variables. Education and income levels were correlated and therefore only education was used as an independent variable.

\section{Key informant interviews}

We conducted 30 semi-structured key informant interviews during February-August 2017, with participants selected from the questionnaire respondents. In these interviews we gathered an in-depth qualitative understanding of questionnaire responses, asking interviewees to elaborate on their choices (Supplementary Material 2), and obtained a broad understanding of the dynamics of Singapore's parrot trade. Data were analysed using qualitative coding for themes and sub-themes (Corbin \& Strauss, 2008). Every theme and sub-theme was analysed and illustrative quotes were retained for each (Supplementary Table 3). This also served to inform sampling, with saturation achieved when no new sub-themes appeared after coding (Guest et al., 2006; Newing, 2011). We also used the interviews and questionnaires to identify the key stakeholder groups involved in Singapore's trade.

\section{Review of Singapore's parrot hobbyist groups}

We reviewed Singapore's parrot hobbyist groups on Facebook in April 2020, classifying them into five categories (hobbyist, lost and found, for sale, free-flying, or interest in specific parrot groups such as cockatiels or African grey parrots), and noting number of members, year founded, status (public/closed), and level of activity (number of posts per month, number of new members per month). The list of parrot hobbyist groups was compiled based on groups mentioned by respondents (Supplementary Table 1) and referenced in local newspaper reports about the growing popularity of parrot ownership (Seetor, 2012; Baker, 2014; Vasko, 2014; Low, 2015; Chan, 2016; Osada, 2016; Woo, 
2018). Both public and private (i.e. closed) groups were searched. We also checked all 'suggested groups' recommended by Facebook, which are based on factors such as recent visits by users, and popularity near the user or close to the user's location in Singapore. Additionally, searches were made on Facebook using the following keywords together with 'Singapore': parrot labels ('parront', 'fid'), hobbyist activity ('free fly', 'free flight'), species groupings ('African grey', 'macaw', 'cockatoo', 'amazon', 'parakeet') and commercial activity ('parrots for sale', 'parrot grooming', 'parrot training'). Other platforms, such as Instagram and online classified platforms, came to our attention during the course of the research, but we did not survey them.

\section{Results}

The 145 questionnaire respondents were predominantly male $(54 \%)$, university educated $(65 \%)$, young $(\leq 30$ years, $36 \%$ ) or middle-aged (31-50 years, $51 \%$ ), with varying income levels and years of experience keeping parrots (Supplementary Table 4). The 30 interviewees had completed the questionnaire survey prior to being interviewed and their questionnaire responses are included in the reporting of the questionnaire survey. The interviewees included not only parrot owners, but also two local parrot breeders, the founder of a parrot hobbyist group, and two parrot sitters, who are paid professionals that provide care for a parrot when the owner is away. Half of the interview respondents were female, and most were young $(\leq 30$ years, $43 \%)$ or $31-50$ years old ( $43 \%)$.

\section{Motivations for ownership}

The results from the questionnaire highlighted a range of individual motivations for and behaviours related to keeping parrots. Respondents owned an average of 4.1 parrots comprising small, medium and large species (Table 1 , Supplementary Table 5). The main reported motivation was 'companionship' (54\%; Fig. 1b) and the most important factor that enabled owners to keep parrots was 'experience/ knowledge to care for parrots' (58\%; Supplementary Table 6). The top three most important considerations when purchasing a parrot were intelligence, trainability and lifespan (Fig. 1C), and 66\% of questionnaire respondents were concerned with the rarity of their parrot, and $22 \%$ were only $0-40 \%$ likely to keep their parrot if it was no longer considered rare (Fig. 1d).

A further motivation for parrot ownership was the purchase of additional parrots as companion birds and the socalled upgrading to larger and exotic species. The majority of questionnaire respondents $(73 \%)$ were satisfied with the number of parrots they owned but $27 \%$ wanted more (Fig. 1e,f). The interviews revealed that the predominant reason for buying additional parrots, especially smaller species such as lovebirds and budgerigars, was as a companion for the parrot(s) they already kept (Table 1). Two interview respondents indicated that it was common for parrot owners to start by keeping smaller-bodied species before upgrading to larger species, many of which are harder to keep but also threatened and highly sought after (e.g. Endangered African grey parrot, Vulnerable hyacinth macaw Anodorhynchus hyacinthinus). They expressed concern that upgrading often resulted in smaller parrots being put up for sale or adoption, or even released into the wild (Table 1).

\section{Awareness of, concern about and willingness to pay for} conservation

The majority of questionnaire respondents (60\%) identified at least one native Singapore parrot but the majority (67\%) did not know the Red List conservation status of the parrots they kept (Fig. 2a). The majority (86\%) of interviewees also lacked awareness about the impacts of trade on wild parrot populations and the extinction risk faced by threatened parrot species in trade. At least five interviewees reported they were unaware of issues with illegal trade and trusted the pet shops to acquire birds from responsible sources (Supplementary Table 3). Several parrot owners perceived species rarity as a function of their abundance in the markets rather than in the wild.

Nevertheless, the majority ( $72 \%$ ) of questionnaire respondents reported they were very concerned about the illegal hunting of parrots for commercial trade (Fig. 2b). They estimated that an average of $46 \%$ of the parrots imported into Singapore were acquired from the wild (Fig. 2e). The majority (85\%) reported that the parrot(s) they kept were captive-bred (Fig. 2c). However, the widespread lack of receipts and paperwork from purchase of their parrots $(83 \%$; Table 1 ) suggests the parrot trade is predominantly based on trust and consumers may not have information to verify the origins of the birds they are buying. Most respondents (70\%) reported a preference for purchasing captive-bred parrots (Fig. 3d), with 70\% reportedly willing to pay more for a sustainably sourced parrot (Fig. 2f). Of these, 20\% were willing to pay more than $40 \%$ of the original cost price of a parrot (Fig. 2f), and most (73\%) were willing to wait a longer time to acquire a sustainably sourced parrot (Fig. $2 \mathrm{~g}$ ).

The level of conservation awareness of respondents was not associated with their level of education or years of experience keeping parrots (Supplementary Table 7). However, their willingness to procure a sustainably sourced pet parrot was strongly associated with their level of education (GLM coefficient $=0.099, \mathrm{P}<0.05, \mathrm{n}=134$ ) and conservation awareness (GLM coefficient $=0.18, \mathrm{P}<0.01, \mathrm{n}=134$; Supplementary Table 7). 
TABLE 1 Key themes and illustrative quotes from the 30 key informant interviews about the parrot trade ecosystem in Singapore (Supplementary Table 3).

\begin{tabular}{|c|c|}
\hline Key themes \& sub-themes & Illustrative quotes \\
\hline \multicolumn{2}{|l|}{ Experiences with pet shops } \\
\hline Introduction to parrots & $\begin{array}{l}\text { When I went to the pet shop I had no intention to keep the parrot (but) the longer I was there, } \\
\text { I knew I would come out with something. } \\
\text { I went to the bird shop to buy bird food, I actually had zero intention of getting a bird but I then } \\
\text { saw one that looked so cute \& so tame. }\end{array}$ \\
\hline Distribution to unlicensed pet shops & $\begin{array}{l}\text { Quite often, some of the licensed bird shops will purchase more birds \& then sell these birds to } \\
\text { other shops that do not have the licenses to import these parrots. Although technically [they] } \\
\text { cannot, they sell it this way to earn money. }\end{array}$ \\
\hline \multicolumn{2}{|l|}{ Supply from private breeders } \\
\hline Preference for private breeders & $\begin{array}{l}\text { I know of many that put their heart into it \& provide so much love for their parrots. } \\
\text { Some home breeders are responsible \& continue to provide advice along the way when needed, } \\
\text { making sure that healthy weaned birds go back to a new \& safe home. }\end{array}$ \\
\hline Private breeders as main suppliers & $\begin{array}{l}\text { Most people I know buy from local breeders, but they are quite silent about it because they } \\
\text { are afraid of people finding out. } \\
\text { Local breeders are one of the main sources of parrots in Singapore, people like to buy from } \\
\text { them because they take care of the parrots better. }\end{array}$ \\
\hline $\begin{array}{l}\text { Private breeders leverage online } \\
\text { platforms }\end{array}$ & $\begin{array}{l}\text { The home breeder publicized the budgie on Facebook. } \\
\text { I bought my first lovebird from Gumtree. }\end{array}$ \\
\hline
\end{tabular}

\section{Hobbyist groups}

Facebook group communities

Private breeders leverage hobbyist networks

Hobbyist group events

Public interest for hobbyist events Hobbyist group participation drives demand

Parrot poisoning

\section{Parrot purchases}

Additional purchases

Upgrading parrots
Through the powerful social media many are introduced \& made aware of parrots' capabilities. Many interesting stories from parrot owners, some even post videos online to tell their stories. There is greater awareness on parrots because of the Facebook groups created; more parrot owners can get together, it is like a community where people learn from one another. Since I read a lot about parrots, I was able to contact the main distributor of a particular brand of parrot food \& started the first online shop selling this unique brand 2 years ago.

Many people start to join the Facebook group, there is a community to free-fly your parrots \& talk about your parrots.

Past 3-4 years, there are more Facebook groups, there is a community, every week they have free-flight events so everyone gathers.

Non-parrot owners will get to see the parrots \& start getting interested in keeping parrots. I saw a Hagoromo budgie on the hobbyist Facebook group for the first time; found it really beautiful \& was keen on getting one after that.

During the parrot hobbyist group events, many people will display their birds. Through that, I saw how smart the African grey was \& wanted it.

We like to influence other people to own parrots-we call it parrot poisoning-we share our passion about owning parrots with others.

We have this term in the parrot community called poisoning-after getting one parrot, we just want more \& more.

There is this idea of evangelizing \& getting people to have a bird. They play up the positive aspects of the birds \& not the negatives, like the cost.

Share with others their passion of owning parrots. . it is fun because parrots have unique personalities \& are intelligent beings.

I bought another lovebird to keep it company.

I wanted to find a male companion for my first female bird.

Some people think they want to start off with small parrots to train their ability to care for parrots then upgrade to bigger parrots after a while \& keep on buying bigger parrots. I think this is very wrong.

\section{Hobbyist groups}

The majority of questionnaire respondents (51\%) identified as a member of at least one parrot hobbyist group (Table 2; Supplementary Table 1), of which $38 \%$ attended in-person meetings once per week or more (Table 2). The interview respondents reported that at least six of the hobbyist groups organize regular (often weekly) meetings in which members socialize and engage in activities such as grooming, freeflying of their parrots and bonding over their shared interest. These activities often draw public attention that indirectly stimulates interest for parrots (Table 1 ). 


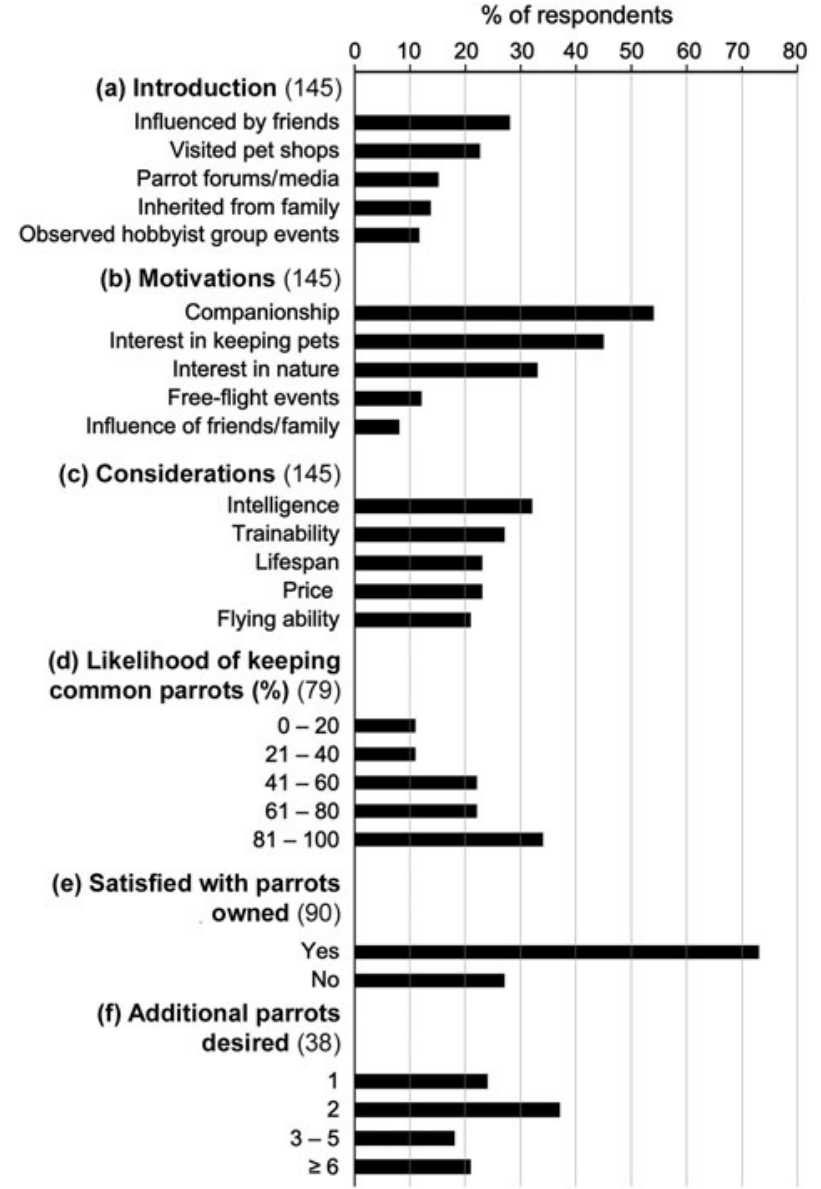

FIG. 1 Motivations for parrot ownership: (a) top five factors influencing how respondents were introduced to parrot keeping, (b) top five motivations for purchasing parrots, (c) top five considerations when purchasing a parrot, (d) likelihood of keeping common parrots, (e) whether satisfied with the number of parrots owned, and (f) how many additional parrots intending to purchase (only answered by respondents who were not pleased with the number of parrots owned). Numbers of respondents for each question are given in parentheses.

Our review on Facebook identified 31 online hobbyist parrot groups in Singapore, all founded since 2012, and 14 established since 2017 (Supplementary Table 8). Ten of the 31 groups specialized in specific parrot groups: lovebirds (Agapornis sp.), cockatiels (Nymphicus sp.), conures, amazons (Amazona sp.), cockatoos (Cacatuidae), rose-ringed parakeets Psittacula krameri, and African grey parrots. The cumulative membership across groups was 57,672 members, although some may be members of multiple groups. The oldest group was also the largest, with 7,950 members. Sixteen of the 31 groups were closed. The larger groups grew by $>100$ new members and had $>500$ posts per month during the period of our review (Supplementary Table 8). These figures suggest that online hobbyist groups are active and growing.

Among hobbyist group members, the majority (64\%) agreed their membership had fuelled their desire to purchase more parrots, in part because they had support

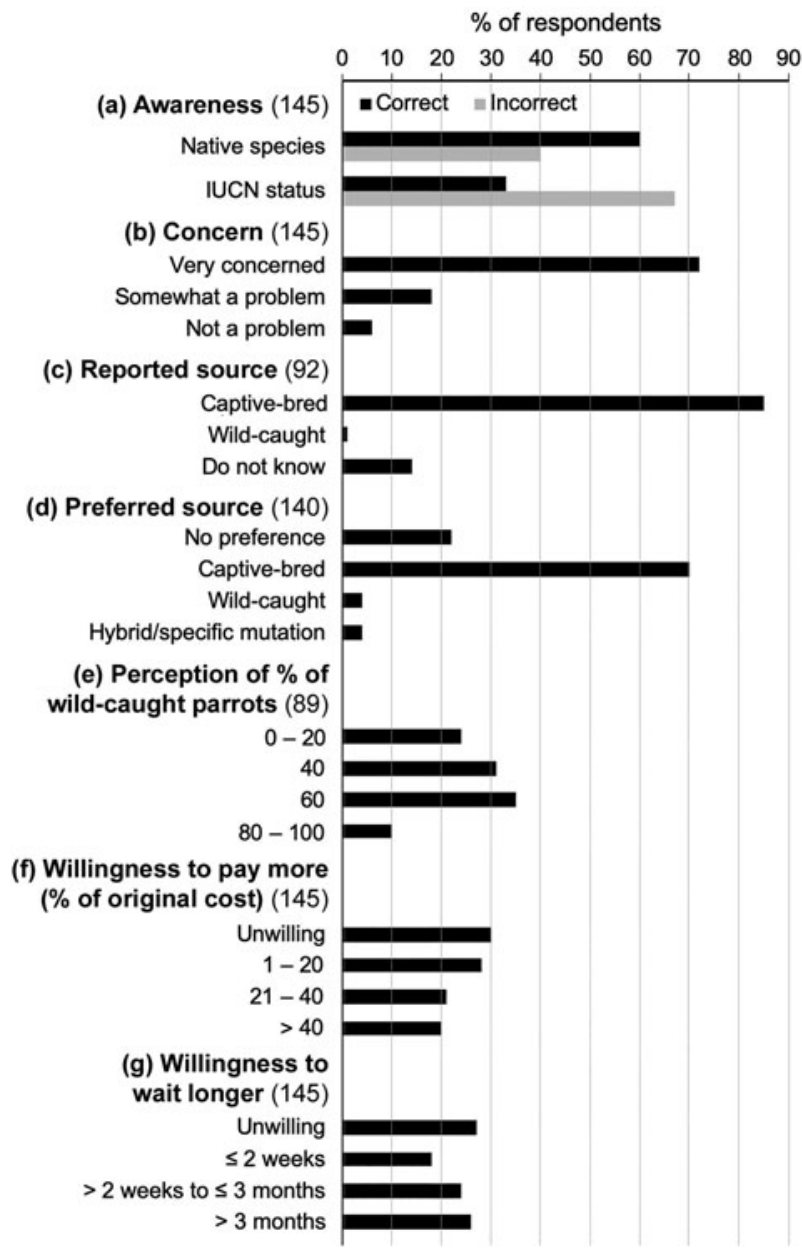

FIG. 2 Respondents' knowledge and views about conservation: (a) awareness of native species and IUCN Red List status of parrots owned (respondents were marked correct if they could identify at least one native parrot and/or provide the correct Red List status for all the parrots they kept), (b) concern about illegal poaching of birds from the wild, (c) reported source of parrot(s) owned, (d) preference for the source of parrots, (e) perception of the per cent of parrots imported in Singapore that are acquired from the wild, (f) willingness to pay extra for parrots from a sustainable source, and (g) willingness to wait to procure a sustainably sourced pet parrot. Numbers of respondents for each question are given in parentheses.

from a community (Table 1 ). This included face-to-face engagement via gatherings and free-flying events, and online interaction to exchange information such as recommendations for parrot products (e.g. toys, food, cages) and services (e.g. vets, grooming, parrot sitting).

\section{Online trade}

The questionnaire respondents reported that $14 \%$ of parrots were purchased online (Table 2), but this is probably an underestimate of the actual prevalence of online sales because some private breeders and pet shops also operate online. Additionally, interview respondents indicated that 
a significant proportion of parrot sales came from advertisements posted on popular classified sites such as chaosadssingapore.com, locanto.sg and chutku.sg and social media platforms including Facebook, Carousel and Instagram. Five of the 10 parrot hobbyist groups mentioned by respondents permitted online sales (Supplementary Table 1), alongside facilitating adoptions and requests for assistance for locating lost parrots (Table 2). At least 13 pet shops had Facebook pages, with five shops having a similar number of likes and followers as the most popular hobbyist groups (Supplementary Table 9).

\section{Private breeders}

The questionnaire responses indicated the importance of private breeders. Thirty per cent of respondents purchased their parrots from private breeders (Table 2), who often leveraged online networks to recommend or sell parrotrelated products and to increase their customer base (Table 1). Twenty of 92 questionnaire respondents $(22 \%)$ reported involvement in home breeding, of which $40 \%$ reported selling parrots and $10 \%$ bred to give away to relatives or friends. The interview respondents also identified private breeders, who were perceived to take better care of parrots and were cheaper than bird shops, as one of the main suppliers of parrots in Singapore (Table 1). Six interviewees indicated that private breeders tended to breed and supply smaller and more common types of parrots such as lovebirds, whereas pet shops tended to specialize in larger, exotic species (Supplementary Table 3).

\section{Singapore's parrot trade ecosystem}

Our findings indicate significant physical and virtual, social and commercial interconnectivity among the stakeholders engaged during this research. This involves parrot owners, pet shops, private breeders, hobbyist groups, breeding centres that deal in high volumes of international import and export of parrots, and a range of supporting industries, including parrot merchandize retailers, grooming services, parrot sitters and free-flying facilities (Fig. 3). These form a dynamic, national and international ecosystem of trade that is creating and shaping Singapore's evolving trade in parrots (Fig. 3).

Pet shops, private breeders and hobbyist groups are of particular importance in shaping the domestic ecosystem, often with interactions mediated via a range of online platforms (Fig. 3, Table 1). For example, our review of online parrot hobbyist groups revealed that popular hobbyist groups recommend Facebook pages of pet shops on their own Facebook pages. We observed at least two pet shops collaborating with hobbyist groups to host regular gatherings for parrot owners to display their parrots outside the pet shops. Such events suggest high interconnectivity between pet shops and hobbyist groups.

The ecosystem metaphor also reflects the dynamics among hobbyists, and key informants explained that many of the consumer motivations and behaviours we observed were probably shaped by interactions within their community (Fig. 3, Table 1). For example, several interview respondents reported they actively encouraged friends and family to keep parrots, a local term known as 'poisoning' among parrot owners (Table 1), which three interviewees reported was a driver for the increase in interest and demand (Table 1, Supplementary Table 3).

\section{Discussion}

\section{Trade dynamics as an ecosystem}

Our map of Singapore's parrot trade ecosystem highlights key stakeholders and their interactions, with a focus on domestic consumers. This differs from trade studies, which typically only highlight trade volumes, trends and routes. The ecosystem metaphor provides an understanding of changing trade relationships among stakeholders. Such relationships are important because existing research on consumer demand for wildlife has highlighted the influence of communities on trade dynamics. For example, Saiga antelope horn consumption among younger Singaporeans is encouraged by the older generation (Theng et al., 2018); demand for elephant ivory products in China and Viet Nam is fuelled by influencers and key opinion leaders such as celebrities (Greenfield \& Veríssimo, 2019); rhinoceros horn consumption in Viet Nam is considered a symbol of power and wealth, and driven by peer pressure amongst the wealthy class to show business success and high social standing (Save The Rhino, 2013); and songbird keeping in Indonesia is heavily influenced by the singing competition community (Marshall et al., 2020) and ecosystem dynamics (Kristianto \& Jepson, 2011). Similarly, parrot hobbyist groups influence the broader domestic consumer demand and trends for parrots in Singapore.

There is scope for adopting an ecosystem approach in other wildlife trade contexts, not only to identify and map key stakeholders but also to uncover the specialist consumer communities that may be driving consumer demand. This can contextualize individual consumers as embedded and influenced by a larger community within the trade system and community, often based on shared interests. Hobbyist groups and societies such as those we have described continue to gain global popularity as an indirect stage for promoting the sale of exotic pets (Nekaris et al., 2013; Siriwat \& Nijman, 2018). Engaging these communities to assess preferences, levels of awareness and support for conservation can help in the design of conservation interventions. Moreover, these communities could potentially become 


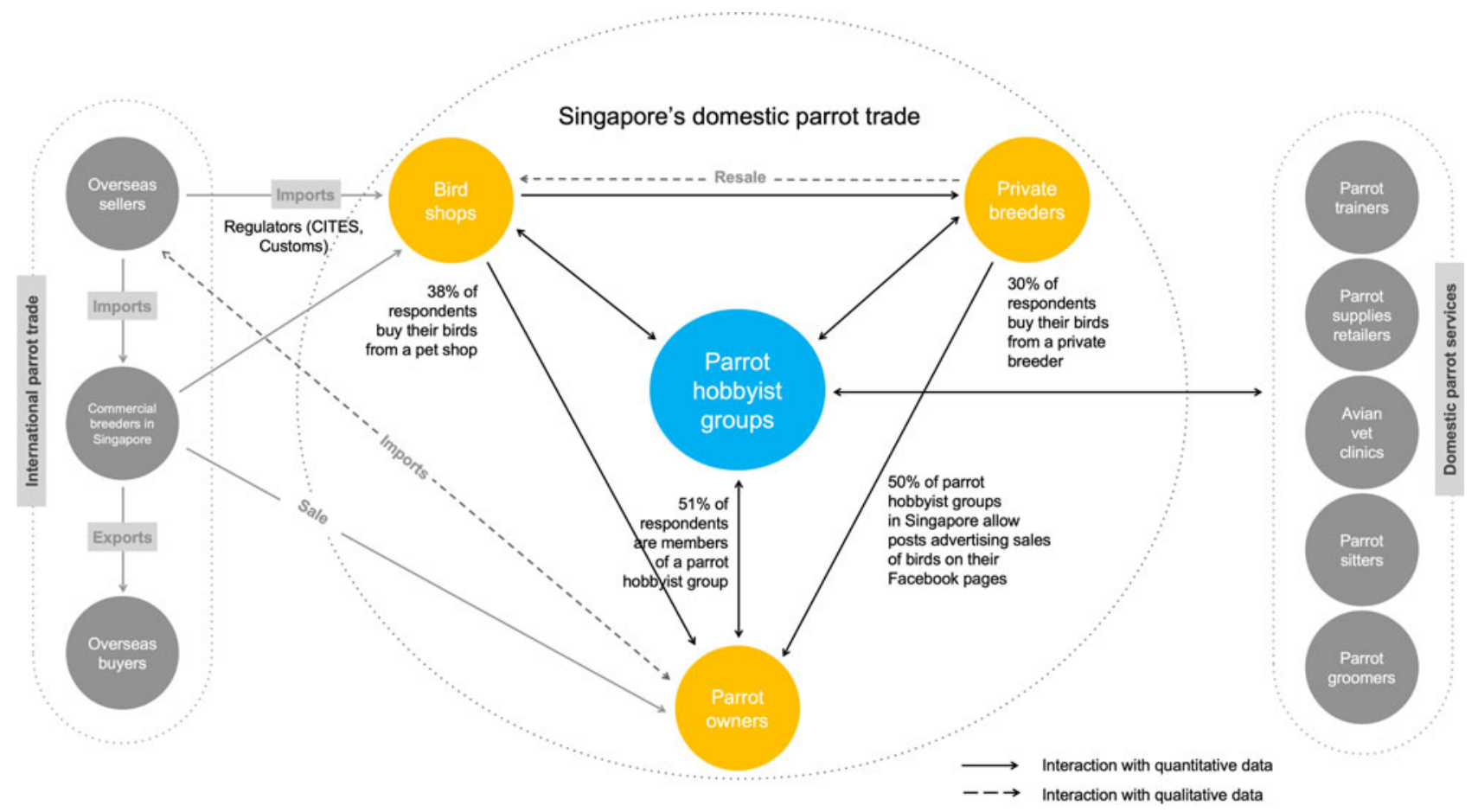

FIG. 3 Overview of Singapore's parrot trade ecosystem, including key international and domestic stakeholders, with arrows indicating interactions that include trade and flow of information, constructed from details provided by the 145 questionnaire respondents (including parrot owners, hobbyist group members, traders, breeders and supporting industry professionals). These interactions happen through both virtual and physical media.

key partners in shaping and delivering measurable conservation interventions, to shape new social norms and change behaviour (Martin et al., 2014). A similar approach of targeted advocacy and awareness raising to address the shark fin trade amongst key stakeholders in the value chain (community members, airlines that ship shark fins and the hotel industry that serves fins at wedding banquets) has reduced use of shark fins in weddings in Singapore (WWF, 2016), and major airlines have banned shark fins from their cargos (Tan, 2014).

\section{Potential for sustainable parrot trade}

Respondents were generally supportive of sustainable trade; they were concerned about illegal hunting of parrots, and reported they were willing to incur higher costs and wait longer to procure a more sustainable pet, even though most lacked an understanding of key conservation issues. This is aligned with findings from other studies that showed respondents' willingness to pay for conservation is correlated with their familiarity and perceived affection towards certain species (Martin-Lopez et al., 2007). Consumer willingness to procure sustainably sourced pets suggests an opportunity to promote legal and sustainable trade in developed cities such as Singapore, where higher education and awareness levels can result in greater consumer support for sustainable practices (GEM report, 2015; Moorhouse et al., 2017). Developed cities are usually centres of demand for exotic pets because of greater affluence, connectivity to international travel and transport of goods, and access to media, information and social trends (Ding et al., 2008; Devulapalli, 2011; Dutton et al., 2013). We recommend promoting captive-bred over wild-caught parrots, taking a conservative approach against promoting sustainably harvested wild parrots because of known issues with corruption, false paperwork and the misrepresentation of quotas from some source countries that supply wild parrots in the region (e.g. Solomon Islands; Shepherd et al., 2012).

Our finding that many consumers purchased birds from small-scale private breeders, and many preferred these breeders over alternative sources, indicates an avenue for unregulated and potentially illegal trade. Some private breeders in Singapore have been fined for operating without a licence (The Straits Times, 2017). Breeding birds privately could also contribute to the spread of zoonotic diseases if the breeding facilities do not have the appropriate health and safety infrastructures for both the birds and owners. Our questionnaire surveys and interviews indicated that the majority of birds were purchased without receipts, which is consistent with informal sector trade. Trade is also harder to police and regulate when it is online (ACRES, 2016; Yin et al., 2020).

There is a need to engage parrot retailers (private breeders and pet shops) and hobbyist groups to promote stronger conservation, particularly as the sector grows. This includes 
TABLE 2 Details of parrot ownership, purchasing and hobbyist group membership from the questionnaire survey respondents ( $n$ indicates the number of survey respondents who answered a particular question).

\begin{tabular}{|c|c|}
\hline Characteristic & Details \\
\hline \multicolumn{2}{|l|}{ Parrot ownership } \\
\hline Bird size $(\mathrm{n}=91)$ & $\begin{array}{l}\text { Number of parrots owned } \\
\text { (mean per respondent, } \\
\text { percentage of total by } \\
\text { all respondents) }\end{array}$ \\
\hline Small $(<200 \mathrm{~g})$ & $2.8(41)$ \\
\hline Medium (200-400 g) & $2.1(30)$ \\
\hline Large $(>400 \mathrm{~g})$ & $2.3(29)$ \\
\hline Mean (irrespective of size) & 4.1 \\
\hline \multicolumn{2}{|l|}{ Purchase details } \\
\hline Place of purchase $(n=84)$ & Number of respondents (\%) \\
\hline Pet shops & $29(35)$ \\
\hline Private breeders & $25(30)$ \\
\hline $\begin{array}{l}\text { Online (including hobbyist } \\
\text { group websites) }\end{array}$ & $12(14)$ \\
\hline Adoption/rehoming & $7(8)$ \\
\hline $\begin{array}{l}\text { Others (including commercial } \\
\text { breeding farms in Singapore) }\end{array}$ & $11(13)$ \\
\hline $\begin{array}{l}\text { Received receipt upon purchase } \\
\quad(\mathrm{n}=143)\end{array}$ & Number of respondents (\%) \\
\hline Yes & $25(17)$ \\
\hline No & $118(83)$ \\
\hline \multicolumn{2}{|l|}{ Hobbyist group membership } \\
\hline $\begin{array}{l}\text { Member of online hobbyist } \\
\text { group }(\mathrm{n}=142)\end{array}$ & Number of respondents (\%) \\
\hline Yes & $73(51)$ \\
\hline No & $69(49)$ \\
\hline $\begin{array}{l}\text { Hobby group in-person } \\
\text { meeting frequency }(\mathrm{n}=69)\end{array}$ & Number of respondents (\%) \\
\hline$\geq 1$ per week & $26(38)$ \\
\hline 1 per $1-6$ months & $22(32)$ \\
\hline$<1$ per 6 months & $21(30)$ \\
\hline $\begin{array}{l}\text { Has being part of a parrot } \\
\text { hobbyist community } \\
\text { encouraged you to want to } \\
\text { own more parrots? }(\mathrm{n}=76)\end{array}$ & Number of respondents (\%) \\
\hline Yes & $49(64)$ \\
\hline No & $27(36)$ \\
\hline
\end{tabular}

establishing guidelines that encourage or mandate retailers to issue receipts and providing customers with information, such as about the source of their animal, health certificates and, potentially, details of their IUCN and CITES status. This would facilitate trade monitoring and the accountability of both buyers and sellers (the majority of our respondents were not aware of the trade implications or conservation status of the parrots they kept, but were concerned about the illegal trade). Hobbyist groups could help to emphasize the threats faced by parrots rather than advertise their rarity.

One way to regulate the complex parrot trade would be the development of a national licensing and bird-ringing or microchip system linked to a centralized registry, to track

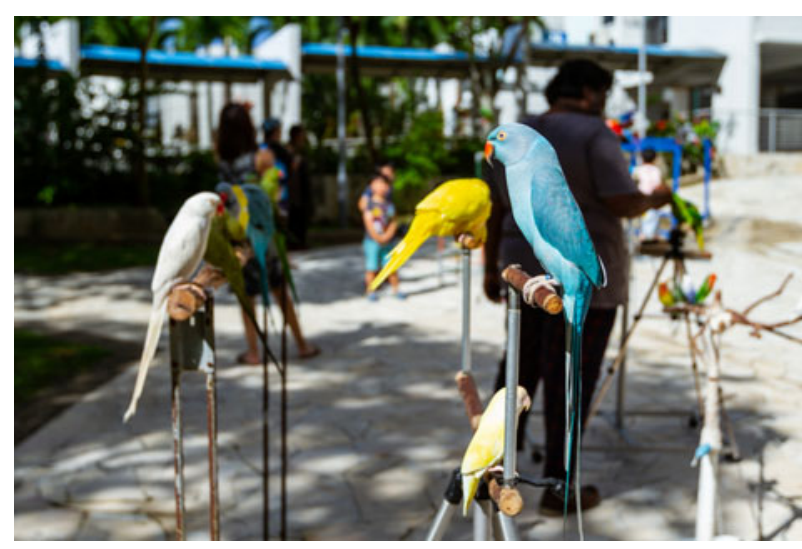

Plate 1 A parrot hobbyist group gathering in west Singapore on 5 January 2020, displaying colour morphs of rose-ringed parakeets Psittacula krameri (in the foreground) and lovebirds Agapornis sp., budgerigars Melopsittacus undulatus, macaws Ara sp., amazons Amazona sp. and grey parrots Psittacus sp. (in the background). Photo: Tim Plowden.

domestic parrot ownership, especially for rare and high-risk species, similar to systems used in the EU and Australia (DBCA, 2013; Pellett \& Cope, 2013; Aloysius et al., 2019). Genetic paternity testing could be used to differentiate captive-bred from wild-caught parrots and to ensure that parrots in trade are at least $\mathrm{F}_{2}$ descendants from wild birds (Coetzer et al., 2017). New licensing conditions could be established and enforced for parrots, similar to that for dogs, cats and rabbits in Singapore (AVS CAW, 2020), which would discourage impulsive purchase, manage potential health and disease issues and pet abandonment, which can negatively affect local ecosystems (Aloysius et al., 2019). Given the large numbers of parrots in trade, regulators could also consider placing restrictions on the import and export of wild-caught species of concern. Together, these measures would ensure a domestic market of responsible suppliers and consumers committed to sustainable trade of captive-bred parrots, supported by appropriate regulations and tracking systems to help reduce illegal and unsustainable trade.

\section{The role of hobbyist groups in shaping trade and conservation}

Formal social networks play key roles in facilitating trade and shaping consumer demand. Most efforts to reduce wildlife demand in Asia have focused on enforcement and punishment for non-compliance with regulations. However, some recent efforts target the individual consumer through conservation campaigns and programmes (Veríssimo \& Wan, 2018), and our findings suggest a potential for this type of targeted community-level intervention.

We also found that hobbyist group members have heterogeneous preferences, with the majority preferring captive-bred birds but a few preferring wild-caught ones. Such trends have also been shown for orchids (Hinsley 
et al., 2015), and reptiles and amphibians (Natusch \& Lyons, 2012). Long-term, cross-cultural preferences have been observed for the most attractive parrot species in Mexico and USA (Tella \& Hiraldo, 2014). This suggests a need to examine such heterogeneity within and across hobbyist groups and to design targeted conservation interventions for different types of hobbyists.

Social networks also have the potential to serve as conduits for promoting conservation and good husbandry practices through virtual (Facebook groups) and physical (meetings and free-flying sessions) community events. These could include outreach and behaviour change campaigns, associated with conservation messages that engage children (Damerell et al., 2013), information about mortality rates in the supply chain, and information about ecological impacts of unsustainable harvesting on wild populations. These groups could also serve as platforms for recommending sustainable sourcing options, including accredited vendors, for establishing codes of conduct for members, and social sanctions for rule-breaking. We believe that many parrot owners in Singapore would be receptive to such messages, as most of our questionnaire respondents were concerned about but unaware of the conservation issues faced by parrots in trade, and were reportedly influenced by their peers in hobbyist groups.

\section{Limitations}

We acknowledge that because the majority of our questionnaire surveys were conducted online, our sample may be biased towards younger and more educated respondents, who are more likely to be engaged in online forums. This may also explain why the respondents' education levels were much higher than the Singapore average (Supplementary Table 4). As we asked respondents about sensitive topics such as the source of their parrots and preference for source (captive-bred, wild-caught or hybrids), some may not have been forthcoming or may have altered their responses in the direction they perceived to be socially desirable (Nancarrow \& Brace, 2000; Choi \& Pak, 2005). Additionally, respondents who participated in the questionnaires and interviews could have potentially been more supportive of conservation, which is why they volunteered to participate. These limitations, when considered together, suggest that our study may represent the best-case scenario, and parrot owners in general may hold a less positive attitude towards conservation than we report.

\section{Conclusion}

Conservation of parrots is dominated by conservation NGOs, government agencies, education institutions and grassroots community efforts. Our mapping of the Singapore parrot trade ecosystem suggests a greater scope to collaborate with consumer hobbyist groups, both online and offline, to shape consumer preferences for conservation gains. These dynamic, growing communities seem to be not only driving trade, but shaping consumer preferences and facilitating trade, but have not yet been leveraged to engage meaningfully with conservation issues. This may be true for many other taxa affected by wildlife trade that have dedicated communities of enthusiasts, such as beetles, ornamental plants (orchids, pitcher plants), songbirds, reptiles, amphibians and fish. Viewing trade and consumption as an ecosystem involving community interactions suggests new opportunities for conservation. The goal is not to halt trade but rather to empower communities to become advocates for responsible and sustainable trade.

Acknowledgements We thank the questionnaire and interview respondents for participating in this research; parrot hobbyist groups for allowing us to join their events; and colleagues from the Nature Society (Singapore) and BirdLife International for constructive comments during the research design and implementation. This research received no specific grant from any funding agency, or commercial or not-for-profit sectors.

Author contributions Design of questionnaire, interview and methods: AJ, SLMA, HL, JGL; fieldwork: SLMA, HL, AJ; online surveys: TP; data analysis, writing: all authors.

\section{Conflicts of interest None.}

Ethical standards All questionnaires and interviews conformed with the British Sociological Association guidelines. The objectives and implications of the research were explained to the participants, who provided freely given and informed consent for their participation. Most of the questionnaire surveys were collected online, with the option for respondents to remain anonymous. Interviews were conducted in person or over the phone, one-on-one, in a quiet setting, and interviews were recorded after seeking the interviewee's consent, and deleted following data analysis. This research abided by the Oryx guidelines on ethical standards.

\section{References}

ACRES (2016) An Investigation Into Pet Shop Conditions for Birds in Singapore 2016. ACRES, Singapore, Singapore.

Aloysius, S., Yong, D.L., Lee, J.G.H. \& Jain, A. (2019) Flying into extinction: understanding the role of Singapore's international parrot trade in growing domestic demand. Bird Conservation International, 29, 1-17.

AVS CaW (Animal and Veterinary Service Code of Animal WELFARE) (2020) Code of animal welfare for the pet industry. Animal \& Veterinary Service, Singapore. nparks.gov.sg/avs/ animals/animal-welfare/animal-and-pets-welfare/code-of-animalwelfare-(for-pet-industry) [accessed 21 April 2020].

BAKer, A. (2014) Young flappy bird owners. Asia One, 10 July 2014. asiaone.com/singapore/young-flappy-bird-owners [assessed 21 April 2020].

Bush, E.R., BaKer, S.E. \& MacDonald, D.W. (2014) Global trade in exotic pets 2006-2012. Conservation Biology, 28, 663-676.

Butchart, H.M.S., Lowe, S., Martin, W.R., Symes, A., Westrip, J.R.S. \& WheAtLey, H. (2018) Which bird species have gone extinct? A novel quantitative classification approach. Biological Conservation, 227, 9-18. 
Chan, A. (2016) Flight of fancy, pricey parrots. The Straits Times, 14 January 2016. straitstimes.com/singapore/flight-of-fancy-priceyparrots [accessed 21 April 2020].

Channel News Asia (2019) Singapore authorities seize 12.7 tonnes of pangolin scales in 2nd haul within a week. Channel News Asia, 10 April 2019. channelnewsasia.com/news/singapore/singaporeauthorities-seize-12-7-tonnes-of-pangolin-scales-in-11429112 [accessed 21 April 2020].

CHOI, B.C.K. \& PAK, A.W.P. (2005) A catalogue of biases in questionnaires. Preventing Chronic Disease, 2, A13.

Coetzer, W.G., Downs, C.T., Perrin, M.R. \& Willows-Munro, S. (2017) Testing of microsatellite multiplexes for individual identification of Cape parrots (Poicephalus robustus): paternity testing and monitoring trade. PeerJ, 5, e290o.

Corbin, J. \& S Trauss, A.L. (2008) Basics of Qualitative Research. 3rd edition. Sage, Thousand Oaks, USA.

Damerell, P., Howe, C. \& Milner-Gulland, E.J. (2013) Childorientated environmental education influences adult knowledge and household behaviour. Environmental Research Letters, 8, 015016.

DBCA (2013) Fauna Licences. Department of Biodiversity, Conservation and Attractions, Australia. dpaw.wa.gov.au/plantsand-animals/licences-and-authorities [accessed 21 April 2020].

Devulapalli, R. (2011) City's rich pet exotic animals. Times of India, 18 December 2011. timesofindia.indiatimes.com/city/hyderabad/ Cityamp39s-rich-pet-exotic-animals/articleshow/11150549.cms [accessed 12 May 2020].

Ding, J., Mack, R.N., Lu, P., Ren, M. \& Huang, H. (2008) China's booming economy is sparking and accelerating biological invasions. BioScience, 58, 317-324.

Doughty, H., Veríssimo, D., Tan, R.C.Q., Lee, J.S.H., Carrasco, L.R., Oliver, K. \& Milner-Gulland, E.J. (2019) Saiga horn user characteristics, motivations, and purchasing behaviour in Singapore. PLOS ONE, 14, e0222038.

Dutton, A., Gratwicke, B., Hepburn, C., Herrera, E.A. \& MACDOnAld, D.W. (2013) Tacking the unsustainable wildlife trade. In Key Topics in Biological Conservation 2 (eds D.W. Macdonald \& K.J. Willis), pp. 74-91. Wiley-Blackwell, Oxford, UK.

Gallagher, S. (2017) Exotic pet owners of Beijing-in pictures. The Guardian, 20 September 2017. theguardian.com/environment/ gallery/2017/sep/2o/exotic-pet-owners-beijing-china-endangeredin-pictures [accessed 21 April 2020].

GEM REPORT (2015) Education increases awareness and concern for the environment. World Education Blog, 8 December 2015. gemreportunesco.wordpress.com/2015/12/o8/education-increasesawareness-and-concern-for-the-environment [accessed 21 June 2020].

Greenfield, S. \& Veríssimo, D. (2019) To what extent is social marketing used in demand reduction campaigns for illegal wildlife products? Insights from elephant ivory and rhino horn. Social Marketing Quarterly, 25, 40-54.

Guest, G., Bunce, A. \& Johnson, L. (2006) How many interviews are enough? An experiment with data saturation and variability. Field Methods, 18, 59-82.

Hinsley, A., Veríssimo, D. \& Roberts, D.L. (2015) Heterogeneity in consumer preferences for orchids in international trade and the potential for the use of market research methods to study demand for wildlife. Biological Conservation, 190, 80-86.

JiN, O.W. (2019) A colourful riot of feathers and symphony of bird song. The Straits Times, 9 August 2019. straitstimes.com/singapore/ a-colourful-riot-of-feathers-and-symphony-of-bird-song [accessed 22 April 2020].

Kristianto, I. \& Jepson, P. (2011) Harvesting orange-headed thrush Zoothera citrina chicks in Bali, Indonesia: magnitude, practices and sustainability. Oryx, 45, 492-499.
Low, D. (2015) Meet the Parronts. The New Paper, 13 December 2015. asiaone.com/meet-parronts [accessed 17 May 2020].

Marshall, H., Collar, N.J., Lees, A.C., Moss, A., Yuda, P. \& MARSDEN, S.J. (2020) Characterizing bird-keeping user-groups on Java reveals distinct behaviours, profiles and potential for change. People and Nature, 2, 877-888.

Martin, S.J., Goldstein, N.J. \& Cialdini, R.B. (2014) The Small BIG: Small Changes That Spark Big Influence. Grand Central Publishing, New York, USA.

Martin-Lopez, B., Montes, C. \& Benayas, J. (2007)

The non-economic motives behind the willingness to pay for biodiversity conservation. Biological Conservation, 139, 67-82.

Minin, E.D., Brooks, T.M., Toivonen, T., Butchart, S.H.M. Heikinheimo, V., Watson, J.E.M. et al. (2019) Identifying global centers of unsustainable commercial harvesting of species. Science Advances, 5, eaau2879.

Moorhouse, T.P., Balaskas, M., D'Cruze, N.C. \& MacDonald, D.W. (2017) Information could reduce consumer demand for exotic pets. Conservation Letters, 10, 337-345.

Nancarrow, C. \& Brace, I. (200o) Saying the 'right thing': coping with social desirability bias in marketing research. Bristol Business School Teaching and Research Review, 3.

Natusch, D.J. \& Lyons, J.A. (2012) Exploited for pets: the harvest and trade of amphibians and reptiles from Indonesian New Guinea Biodiversity and Conservation, 21, 2899-2911.

Nekaris, K.A.I., Campbell, N., Coggins, T.G., Rode, E. \& Nijman, V. (2013) Tickled to death: analysing public perception of 'cute' videos of threatened species (slow lorises-Nycticebus spp.) on web 2.0 sites. PLOS ONE, 8, e69215.

Newing, H. (2011) Conducting Research in Conservation: A Social Science Perspective. Routledge, London, UK.

Nijman, V. (2010) An overview of international wildlife trade from Southeast Asia. Biodiversity Conservation, 2010, 1101-1114.

Olah, G., Butchart, S.H.M., Symes, A., Guzman, I.M., Cunningham, R., Brightsmith, D.J. \& Heinsohn, R. (2016) Ecological and socio-economic factors affecting extinction risk in parrots. Biodiversity and Conservation, 25, 205-223.

Osada, J. (2016) Bird owners of a feather flock together. The Strait Times, 14 January 2016. straitstimes.com/singapore/bird-owners-ofa-feather-flock-together [accessed 21 April 2020].

Pellett, S. \& Cope, I. (2013) Identification using microchips in exotic species. Companion Animal, 8, 172-176.

Pires, S.F. (2012) The illegal parrot trade: a literature review. Global Crime, 13, 176-190.

Poole, C.M. \& Shepherd, C.R. (2016) Shades of grey: the legal trade in CITES-listed birds in Singapore, notably the globally threatened African grey parrot Psittacus erithacus. Oryx, 51, 411-417.

R Core Team (2019) R: A Language and Environment for Statistical Computing. R Foundation for Statistical Computing, Vienna, Austria. r-project.org [accessed 19 March 2021].

Save The Rhino (2013) The Vietnam Question. savetherhino.org/ thorny-issues/the-vietnam-question [accessed 21 April 2020].

Seetor, B. (2012) Man starts club to help owners train parrots. The New Paper, 3 December 2012. asiaone.com/print/News/Latest\% ${ }_{2} \mathrm{BNews} / \mathrm{Singapore} /$ Story/A1Story20121202-387158.html [accessed 21 April 2020]

Shepherd, C.R., Stengel, C.J. \& Nijman, V. (2012) The Export and Re-Export of CITES-Listed Birds from the Solomon Islands. TRAFFIC Southeast Asia, Selangor, Malaysia.

Singstat (2020) Singapore Population. Department of Statistics, Singapore. singstat.gov.sg/modules/infographics/population [accessed 14 April 2021]. 
Siriwat, P. \& Nijman, V. (2018) Illegal pet trade on social media as an emerging impediment to the conservation of Asian otters species. Journal of Asia-Pacific Biodiversity, 11, 469-475.

Sivapriyan, E.T.B. (2018) Exotic pets recovered in Chennai. Deccan Herald, 9 October 2018. deccanherald.com/national/exotic-petsrecovered-chennai-696896.html [accessed 21 April 2020].

TAN, S.W. (2014) SIA cargo to stop carrying shark's fin from August. Today Online, 30 June 2014. todayonline.com/singapore/sia-cargostop-carrying-sharks-fin-august [accessed 11 May 2020].

TAN, S.-A. (2019) NParks to review, tighten standards in pet industry. The Straits Times, 18 August 2019. straitstimes.com/singapore/ nparks-to-review-tighten-standards-in-pet-industry [accessed 21 April 2020].

Tella, J.L. \& Hiraldo, F. (2014) Illegal and legal parrot trade shows a long-term, cross-cultural preference for the most attractive species increasing their risk of extinction. PLOS ONE, 9, e107546.

The Straits Times (2017) Man fined \$2,750 for operating illegal pet shop with 27 caged parrots in HDB flat. The Straits Times, 16 November 2017. straitstimes.com/singapore/courts-crime/manfined-2750-for-operating-illegal-pet-shop-with-27-caged-parrotsin-hdb [accessed 22 April 2020].

Theng, M., Glikman, J.A. \& Milner-Gulland, E.J. (2018) Exploring Saiga horn consumption in Singapore. Oryx, 52, 736-743.

Thomas-Walters, L., Hinsley, A., Bergin, D., Doughty, H., Eppel, S., MacFarlane, D. et al. (2020) Motivations for the use and consumption of wildlife products. Conservation Biology, $35,483-491$.
TRAFFIC (2016) Singapore's Wild Bird Trade Raises Troubling Questions About African Grey Parrots. traffic.org/home/2016/4/18/ singapores-wild-bird-trade-raises-troubling-questions-about.html [accessed 21 April 2020].

UnOdC (United Nations Office on Drugs and Crime) (2016) World Wildlife Crime Report: Trafficking in Protected Species, 2016. New York, USA.

Vasko, L. (2014) Parrot passion. The Straits Times, 22 February 2014. straitstimes.com/singapore/parrot-passion [accessed 21 April 2020].

Veríssimo, D. \& Wan, A.K.Y. (2018) Characterizing efforts to reduce consumer demand for wildlife products. Conservation Biology, $33,623-633$.

Woo, A. (2018) Training birds to free-fly takes off among enthusiasts. The Straits Times, 6 April 2018. straitstimes.com/lifestyle/trainingbirds-to-free-fly-takes-off-among-enthusiasts [accessed 21 April 2020].

WWF (2016) Singaporeans Would Support Government Moves to Protect Sharks-Finding of WWF Consumer Report. WWF Singapore, Singapore. wwf.sg/?26073o/Singaporeans-wouldsupport-government-moves-to-protect-sharks---findings-ofWWF-consumer-report [accessed 11 May 2020].

Yin, R.-Y., Ye, Y.-C., Newman, C., Buesching, D., Macdonald, D.W., Luo, Y. \& ZHOU, Z.-M. (2020) China's online parrot trade: generation length and body mass determine sales volume via price. Global Ecology and Conservation, 23, e01047.

ZHENG, M. \& LEUNG, R. (2018) Why are more Hongkongers going wild for exotic pets? South China Morning Post, 4 August 2018. scmp.com/news/hong-kong/community/article/2158232/whyare-more-hongkongers-going-wild-exotic-pets [accessed 21 April 2020]. 